\title{
Rusunawa dan Sandwich Generation: Resiliensi Masa Pandemi di Ruang Perkotaan
}

\author{
${ }^{1}$ Genta Mahardhika Rozalinna \\ Tenaga Pengajar Sosiologi FISIP \\ Universitas Brawijaya \\ gmrozalinna@ub.ac.id \\ ${ }^{2}$ Violetta Lovenika Nur Anwar \\ Mahasiswa Program Studi S1 Sosiologi FISIP \\ Universitas Brawijaya \\ violettalna@student.ub.ac.id
}

Keywords:

Resilient city; sandwich generation;

rusunawa; urban

resilience;

Kota tangguh; resiliensi perkotaan; rusunawa;

sandwich generation

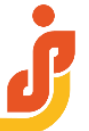

BRAWIJAYA JOURNAL of SOCIAL SCIENCE

Vol.1,No.1,2021

DOI:

https://doi.org/10.2

1776/ub.bjss.2021.0

$\underline{01.01 .5}$

Submitted:2021-11-16

Accepted:2021-12-01

\section{Abstract}

This study aims to analyze resilience from sandwich generation during the pandemics concerning the needs for living place (rusunawa) in city space East Java province. Rusunawa is a part of strategic plan from Flats directorate, ministry of public works and society housing in 2020-2024 which provides new houses for about 107-967 units through program flats building, special house and stimulant budget for constructing new self-subsistent house. Rusunawa is made especially for the people who has low income, and were built in around 18.380 unit. The method of taking data is using in-depth interviews on four members of sandwich generation which located in Malang, Probolinggo, Surabaya, and Sidoarjo also second data resources in form of empirical study report and government documents which related strategic plan rusunawa construction, the number of sandwich generation, also number of possession status of the rental house. The result is the narratives of experiences of sandwich generation for choosing a place to live also the interaction that happened among the sandwich generation in defining urban resilience. This debate happens in the context of understanding and embedding the word of tough and defense city in the thought of the sandwich generation. The economy factor happened dominantly to the sandwich generation for choosing the needs of a place to live other than the capacity of economy capacity, human, also disturbance during pandemic. All together think about the economy capacity which they had in a way of more to choose a place to stay with ste status of 'rental house' than possesed their own house without considering another capacities in the elements of city defense. This thing become contradictory in the middle of effort of the government which getting intense to the evaluation of indicator of the tough city for manifesting city defense. 


\section{Abstrak}

Tulisan ini bertujuan menelaah resiliensi dari sandwich generation di masa pandemi tentang kebutuhan tempat tinggal (rusunawa) di ruang perkotaan Provinsi Jawa Timur. Rusunawa merupakan bagian dari Rencana Strategis (Renstra) Direktorat Rumah Susun, Kementerian Pekerjaan Umum dan Perumahan Rakyat pada tahun 2020-2024 yang menyediakan rumah baru sejumlah 107.967 unit melalui kegiatan pembangunan rumah susun, rumah khusus dan dana bantuan stimulan pembangunan baru rumah swadaya. Rusunawa dikhususkan salah satunya untuk Masyarakat Berpenghasilan Rendah (MBR) dengan jumlah 18.380 unit. Metode pengambilan data menggunakan teknik wawancara mendalam kepada empat sandwich generationyang bertempat tinggal di kawasan Malang, Probolinggo, Surabaya, dan Sidoarjo serta sumber data sekunder berupa laporan studi empiris dan dokumen-dokumen pemerintahan yang terkait dengan rencana strategis pembangunan rusunawa, jumlah usia sandwich generation, serta jumlah status kepemilikan rumah sewa. Hasilnya adalah pengalaman-pengalaman para sandwich generation dalam memilih tempat tinggal serta interaksiinteraksi yang berjalin kelindan di antara para sandwich generation dalam mendefinisikan ketahanan kota (urban resilience). Perdebatan ini terjadi pada konteks pemahaman penyematan kata kota tangguh atau ketahanan kota dalam pemikiran para sandwich generation. Faktor ekonomi menjadi dominan pada diri para sandwich generation untuk memilih kebutuhan tempat tinggal ketimbang urusan kapasitas ekosistem, manusia, serta gangguan selama masa pandemi. Semuanya sama-sama memikirkan kapasitas ekonomi yang mereka miliki dengan cara lebih memilih kebutuhan tempat tinggal dengan status "rumah sewa" daripada rumah sendiri, tanpa memikirkan kapasitas-kapasitas lainnya di dalam unsur ketahanan perkotaan. Hal ini menjadi kontradiktif di tengah upaya pemerintah yang semakin gencar dalam penilaian indikator kota tangguh untuk mewujudkan ketahanan perkotaan.

\section{Pendahuluan}

Termaktub dalam Rencana Strategis (Renstra) Direktorat Rumah Susun, Kementerian Pekerjaan Umum dan Perumahan Rakyat tahun 2020-2024 terdapat penyediaan rumah baru sejumlah 107.967 unit melalui kegiatan pembangunan rumah susun, rumah khusus dan dana bantuan stimulan pembangunan baru rumah swadaya (PUPR, 2020). Sebelumnya pada tahun 2015-2019 sebanyak 48.792 unit rumah susun telah dibangun, salah satunya adalah rumah susun untuk Masyarakat Berpenghasilan Rendah (MBR) sebanyak 18.380 unit (PUPR, 2020). Penyediaan rumah oleh Kementerian PUPR telah meningkatkan status kepemilikan rumah dalam dasawarsa terakhir sebesar 80\% yang termasuk ke dalam Rencana Pembangunan Jangka Menengah Nasional (RPJMN) 2020-2024 melalui strategi perumahan khususnya penyediaan akses perumahan dan permukiman yang layak, aman dan terjangkau serta berada di kawasan perkotaan dengan model vertikal. 
Namun demikian, proyek penyediaan rumah untuk MBR menemui beberapa masalah seperti ketersediaan lahan yang terbatas, tidak adanya anggaran khusus untuk penyediaan lahan, serta yang menarik adalah lemahnya kontribusi pihak swasta dalam penyediaan rumah susun sebagai dampak belum lengkapnya regulasi dan akibat dari kurangnya insentif yang didapatkan oleh mereka saat pembangunan rumah susun sewa. Maka dengan menelusuri permasalahan yang ada, disediakan beberapa solusi seperti penyediaan rumah susun dengan kerjasama yang baik antara swasta, badan usaha maupun masyarakat dan peningkatan kapasitas bantuan dari pemerintah untuk penyediaan rumah. Solusi yang disediakan berjalin kelindan dengan tujuan direktorat khusus pada dua hal yaitu peningkatan ketersediaan dan kemudahan akses serta efisiensi pemanfaatan air untuk memenuhi kebutuhan domestik, peningkatan produktivitas pertanian, pengembangan energi, industri dan sektor ekonomi unggulan, konversi dan pengurangan risiko/kerentanan bencana alam serta pemenuhan kebutuhan perumahan dan infrastruktur permukiman yang layak dan aman untuk terwujudnya smart living melalui pengelolaan yang partisipatif guna peningkatan kualitas hidup masyarakat.

Peningkatan kualitas hidup masyarakat sendiri masuk ke dalam target dari Sustainable Development Goals (SDG's) dengan tujuan dan sasaran nomor sebelas yaitu sustainable cities and communities (PUPR, 2020). Indikatornya adalah tersedianya akses rumah yang layak huni, ketahanan konstruksi bangunan, kemudahan akses air minum, sanitasi serta luasan perkapita. Peningkatan tersebut didukung oleh arah kebijakan pembangunan rumah susun terutama untuk MBR, berada pada kawasan metropolitan perkotaan - transit oriented development (TOD), pembangunan pada kawasan-kawasan strategis, pembangunan berskala besar, pemanfaatan teknologi beserta bahan bangunan yang ramah lingkungan termasuk juga cara perawatannya. Selain masuk ke dalam target dari SDG's, penyelenggaraan kota menjadi wewenang dari konteks otonomi daerah (Bratakusumah, 2000). Beberapa negara sedang melakukan desentralisasi untuk memperbaiki mutu layanan kepada masyarakat dari penyelenggara pemerintahan. Yang paling berat adalah bukan tentang bagaimana memberikan pelayanan, namun bagaimana pemerintah melakukan pendekatan dengan masyarakat. Pun halnya yang disampaikan oleh Campanella (Campanella, 2006), bahwa seharusnya penyelenggaraan kota haruslah melibatkan masyarakat karena masyarakat adalah perkumpulan orang yang menempati ruang perkotaan.

Pembagian kewenangan pada pemikiran masyarakat ditentukan oleh siapa yang akan menerima suatu manfaat dan siapa yang akan menanggung beban atau risiko/dampak (Bratakusumah, 2000). Menurut UU No. 22 Tahun 1999 tentang Pemerintahan Daerah, telah diatur secara jelas tentang kewenangan dari pemerintah di tingkat lokal dan keseluruhan di bidang pemerintahan. Pada UU tersebut dinyatakan bahwa "mengatur dan mengurus kepentingan masyarakat setempat menurut prakarsa sendiri berdasarkan aspirasi masyarakat dalam ikatan negara kesatuan Republik Indonesia", secara khusus pada pasal 91, yang telah diatur tentang cara pengelolaan kawasan perkotaan. Pengelolaan tersebut mulai dari penyelenggaraan wajib seperti pekerjaan umum, kesehatan, pendidikan dan kebudayaan, pertanian, perhubungan, 
industri dan perdagangan, penanaman modal, lingkungan hidup, pertanahan, koperasi, tenaga kerja. Tambahan lainnya pada ruang perkotaan secara khusus adalah tersedianya pemadam kebakaran, kebersihan, pertamanan, dan tata kota. Penyelenggaraan kota semuanya ditujukan untuk peningkatan kualitas hidup bagi semua pihak yang menempati kawasan perkotaan.

Terlepas dari peningkatan kualitas hidup, pertanyaan kritis diajukan oleh Vale (2014), tentang siapakah yang menginginkan peningkatan kualitas hidup pada masyarakat perkotaan? Siapakah yang seharusnya bertanggung jawab atas peningkatan kualitas hidup pada masyarakat perkotaan? Serta bagaimana cara meningkatkan kualitas hidup dari masyarakat perkotaan?. Menurut Vale (2014), kota diciptakan dan diperuntukkan bagi orang yang memiliki kuasa sebab bagi mereka orang-orang yang rentan pada ruang perkotaan dianggap tidak mampu untuk mengakses segala fasilitas yang disediakan di ruang perkotaan. Apabila ide penyelenggaraan kota yang seharusnya untuk meningkatkan kesejahteraan hidup semua pihak, namun menurut Vale justru kota tidaklah untuk menyejahterahkan semuanya, maka pembangunan perkotaan akan menjadi masalah bagi pihak-pihak yang terpinggirkan.

Penekanan pada konteks ruang perkotaan cukup kompleks mengingat kata kota dalam Bahasa Inggris yaitu city yang berasal dari Bahasa Latin yaitu civitas yang berarti peradaban suatu wilayah geografis tertentu (Padawangi, 2018). Peradaban menyiratkan kota lebih dari ruang permukiman namun juga menyimbolkan identitas geografis tertentu. Simbol dari kota ditandai dengan hadirnya aktivitas urbanisasi yang menghasilkan mobilitas ekonomi dan sosial serta pertukaran simbol-simbol budaya. Kota menjadi simbol pertumbuhan cepat dari skala baru urbanisasi dalam menghadapi berbagai polemik masyarakat yang menempel. Urbanisasi telah mendorong para pemangku kebijakan bergandeng tangan dengan para perancang perkotaan serta masyarakat dalam menciptakan kota khususnya tempat tinggal yang aman dan nyaman bagi masyarakat. Namun tidak seperti yang dinyatakan oleh Vale (2014), bahwa keamanan dan kenyamanan akan lebih mudah didapat oleh masyarakat dengan penghasilan ekonomi menengah ke atas.

Tempat tinggal yang aman dan nyaman bagi masyarakat berada dalam dua titik persimpangan yakni tujuan dari program pemerintah ataukah fantasi belaka. Mengingat urbanisasi telah membawa pemerintah, khususnya di Pulau Jawa, untuk merencanakannya di dalam peta jalan pembangunan rumah susun di Indonesia dengan angka tertinggi sebanyak 22.497 unit dari 51.340 unit yang disediakan di seluruh Indonesia (PUPR, 2020). Itu artinya hampir 50\% pembangunan rumah susun disediakan di Pulau Jawa. Pembangunan tersebut dianggarkan khusus untuk Pulau Jawa sebesar Rp 8.322.224.000.000,00 dari Rp 18.515.580.000.000,00 (PUPR, 2020). Dari anggaran yang disediakan antara tahun pembangunan 2020-2024, Pulau Jawa menempati posisi anggaran tertinggi untuk pembangunan rumah susun di Indonesia. Seharusnya pembangunan rumah susun di Pulau Jawa dapat menjawab tingkat kebutuhan permukiman, namun kenyataannya tidaklah selalu demikian. Kenyataannya adalah 
permasalahan ini semakin terlihat pada generasi yang disebut dengan sandwich generation.

Sandwich generation adalah generasi setengah baya yang memiliki orang tua lanjut usia dan memiliki tanggungan kepada anak-anaknya (Kusumaningrum, 2018). Istilah tersebut pertama kali digunakan oleh Dorothy Miller tahun 1981 dalam tulisannya tentang "The Sandwich Generation: Adult of the Aging" (Husain et al., 2021). Istilah ini dianalogikan seperti memakan sebuah kudapan sandwich, yaitu sepotong daging yang terjepit di antara dua helai roti (Anonim, 2021). Analogi tersebut sama halnya dengan kondisi pada seseorang yang memiliki beban tanggungan terhadap orang tua dan juga anak-anaknya. Artinya, sandwich generation ini juga menggambarkan suatu kondisi bahwa mereka sedang terjepit dalam suatu pilihan antara harus menanggung orang tua ataukah anak-anaknya. Menanggung orang tua dan keluarga yang dimaksudkan di sini dapat berupa tanggungan ekonomi ataupun pengasuhan kepada orang tua dan kebutuhan anak-anak pada generasi sandwich. Menurut pengertian dari generation sandwich dapat dikatakan bahwa kondisi ini dapat terjadi baik pada perempuan maupun laki-laki. Kemudian, kondisi ini juga dapat melahirkan suatu permasalahan baru bagi generasi sandwich di mana mereka memiliki beban tanggungan yang berat, bahkan tidak hanya fisik, namun juga pada mental yang dapat memicu stress (Husain et al., 2021). Sebenarnya fenomena sandwich generation ini telah ada sejak lama di lingkungan masyarakat. Bahkan fenomena sandwich generation menjadi suatu rantai budaya yang belum dapat terselesaikan hingga saat ini. Tidak jarang juga, banyak sandwich generation lebih mementingkan kebutuhan orang tuanya daripada diri sendiri maupun anakanaknya. Hal tersebut dapat didasari karena pengaruh doktrin lingkungan keluarganya bahwa anak harus berbakti kepada orang tua.

Sandwich generation merupakan gabungan dari generasi X (41-60 tahun) dan Y (26-40 tahun) yang menanggung generasi baby boomer dan generasi Z (PUPR, 2020). Menurut data BPS provinsi Jawa Timur tahun 2018-2020 menunjukkan jumlah dari generasi $X$ adalah 36.076.904 jiwa dan generasi $Y$ adalah 26.756.927 jiwa sehingga totalnya sejumlah 62.833.831 juta (Data BPS tahun 2018-2020). Generasi X dan Y telah diasumsikan sebagai generasi yang telah menjadi orang tua dan menanggung beban anak serta orang tuanya. Terlebih dalam kultur Indonesia, sistem perkeberatan dalam menanggung orang tua di saat anak menjadi dewasa dan telah ataupun belum mendapat pekerjaan adalah perihal yang lazim ditemui.

Tabel 1. Data Jumlah Usia

\begin{tabular}{llll}
\hline \multirow{2}{*}{ Tipe-Tipe Generasi } & \multicolumn{4}{l}{ Tahun } & \\
\cline { 2 - 4 } & $\mathbf{2 0 1 8}$ & $\mathbf{2 0 1 9}$ & $\mathbf{2 0 2 0}$ \\
\hline Generasi baby boomer & 4.993 .000 & 4.140 .990 & 4.303 .506 \\
\hline Generasi X & 10.879 .000 & 10.973 .050 & 14.224 .854 \\
\hline Generasi Y & 8.689 .000 & 8.666 .298 & 9.401 .629 \\
\hline Generasi Z & 9.134 .000 & 9.123 .622 & 9.089 .921 \\
\hline Generasi alpha & 5.805 .000 & 5.752 .214 & 5.745 .250 \\
\hline
\end{tabular}

Sumber: Olahan Data BPS Provinsi Jawa Timur Tahun 2019-2021 
Di antara para sandwich generation, tidak semuanya memiliki tempat tinggal. Terkadang mereka memilih untuk tinggal di rumah orang tua, mertua, ataupun sanak saudara yang memiliki kamar kosong. Pertengkaran pun sering terjadi pada generasi ini karena keterbatasan ruang yang memberikan mereka kebebasan. Pada akhirnya daripada bertempat tinggal dengan orang tua, mertua, ataupun sanak saudara, program dari pemerintah untuk pemenuhan kebutuhan tempat tinggal berupa rusunawa menjadi pilihan. Misalnya penelitian yang dilakukan oleh Rahmawati (2018), yang menunjukkan bahwa bertempat tinggal di hunian vertikal membutuhkan kesiapan tinggal yang melibatkan warga huni, perwakilan warga huni dalam paguyuban, dan pengelola. Kesiapan tersebut terkait dengan cara seseorang dalam menyimpulkan identitas sosial yang berasal dari keanggotaan di dalam suatu kelompok. Menurut Rahmawati, integritas dan koneksi sosial menjadi dua kunci penting yang membutuhkan perhatian khusus pada dimensi rasa komunitas. Kemudian dalam kontrol sosial, komitmen dan keterlibatan merupakan dua hal yang perlu diperhatikan untuk dapat menghasilkan keseimbangan sistem tinggal di rusunawa. Bila ditilik lebih dalam maka dalam penelitian Rahmawati belum secara spesifik merujuk pada kategori usia secara jelas yang dapat menunjukkan kelompok manakah yang seharusnya mendapatkan perhatian khusus di dalam komunitas. Prinsipnya, semakin terjepit hidup seseorang dalam konteks ekonomi, sosial, budaya maka membuat seseorang sangat membutuhkan perhatian lebih.

Pada penelitian terdahulu lainnya yang membahas tentang aktor fisik bangunan, beberapa kajian memperlihatkan bahwa perasaan sejahtera dalam menghuni dapat muncul karena beberapa faktor diantaranya adalah rasa aman (Mohit, Ibrahim \& Rashid, 2010), privasi dan desain ruang (Day, 2000), ukuran ruangan dan lamanya bertempat tinggal (Fang, 2006; Berkoz, Turk \& Kellekci, 2009). Namun pada penelitian-penelitian tersebut belum memperlihatkan intervensi negara dalam kepengaturan faktor-faktor perasaan sejahtera. Misalnya pada konteks keterlibatan negara dan perancang perkotaan (rusunawa) pada pembangunan rusunawa guna mencukupi kebutuhan tempat tinggal. Sehingga dalam konteks ini, perasaan sejahtera tidak hanya bertumpu pada kepuasaan internal namun pada struktur kota yang melekat pada kehidupan masyarakat perkotaan.

Struktur kota yang mampu membuat masyarakat yang tinggal di dalamnya semakin resiliensi dapat menjadi perhatian menarik sebab kajian-kajian tentang resiliensi semakin berkembang seiring dengan bertambahnya keilmuan yang membahas ini seperti ekologi, psikologi, sosial dan ekonomi (Chelleri, 2012). Awalnya untuk merujuk tentang kapasitas ekosistem, manusia, masyarakat, ekonomi, dan baru-baru saja tentang sistem perkotaan untuk mengatasi gangguan. Kondisi struktur tidak dapat ditebak saat situasi gangguan belum muncul, gangguan yang dimaksud adalah gangguan yang terjadi pada orang-orang yang bertempat tinggal di rusunawa. Namun apabila gangguan hanya diartikan sebagai sesuatu yang terkait dengan kapasitas dalam mempertahankan fungsi dan struktur maka konteks resiliensi perkotaan tidak dapat dipaksakan memasuki ranah definisi ini, melainkan akan didefinisikan sebagai kota tangguh. Kota tangguh sendiri pada akhirnya menjadi embrio resiliensi perkotaan. 
Situasi pandemi di ruang perkotaan menjadi sebuah tantangan untuk berbagai kalangan terlebih pada sandwich generation. Hal ini disebabkan karena sebelum situasi pandemi mereka masuk ke dalam kategori kelompok rentan, misalnya dari sisi ekonomi, kesehatan, dan sosial. Di lain sisi para sandwich generation yang tinggal di rusunawa merupakan para pendatang di kota seperti Malang, Probolinggo, Surabaya, dan Sidoarjo. Tantangan bagi sandwich generation di masa pandemi pada ruang perkotaan bukan lagi keterbatasan ekonomi, melainkan juga akses untuk memperoleh kesehatan yang baik. Ditambah lagi, dengan situasi dan kondisi pandemi Covid-19 yang memakan banyak korban dengan ancaman kematian. Ketakutan-ketakutan sandwich generation di masa pandemi tersebut memaksa mereka untuk tetap bertahan di segala kondisi dengan keterbatasan akses ekonomi, kesehatan, hingga tempat tinggal di rusunawa yang kemudian dialihfungsikan menjadi tempat penampungan pasien Orang Tanpa Gejala (OTG) Covid-19. Adapun penelitian ini menelusuri pemikiran sandwich generation dalam menempati rusunawa di tengah resiliensi masa pandemi ruang perkotaan.

\section{Metode Penelitian}

Studi ini menggunakan metode penelitian kualitatif deskriptif yang berusaha untuk menggali dan menelaah data dengan lebih mendalam tentang resiliensi di masa pandemi oleh sandwich generation yang bertempat tinggal di rusunawa dalam ruang perkotaan. Para informan dipilih berdasarkan kriteria sebagai berikut: 1) tinggal di rusunawa perkotaan yang terletak di Provinsi Jawa Timur. Hal tersebut termaktub dalam Rencana Strategis Direktorat Rumah Susun, Pulau Jawa menempati rencana pembangunan tertinggi khususnya di Provinsi Jawa Timur yang memiliki jumlah pembangunan sebanyak 5.625 unit, sedangkan Provinsi Banten sebanyak 1.911 unit, Provinsi Jawa Barat sebanyak 3.548 unit, Provinsi DKI Jakarta sebanyak 4.900 unit, Provinsi Jawa Tengah sebanyak 4.458 unit, dan Provinsi Daerah Istimewa Yogyakarta (DIY) sebanyak 2.055 unit (PUPR, 2020); 2) berpenghasilan rendah di bawah UMR regional di tempat mereka tinggal sehingga masih kesulitan untuk dapat membeli rumah. Teknik penggalian data menggunakan wawancara mendalam kepada empat sandwich generation yang terdiri dari tiga orang berusia 26-40 tahun (generasi $X$ ) dan satu orang berusia 41-60 tahun (generasi $Y$ ), serta sumber data sekunder berupa laporan studi empiris dan dokumendokumen pemerintahan yang terkait dengan rencana strategis pembangunan rusunawa, jumlah usia sandwich generation, serta jumlah status kepemilikan rumah sewa.

\section{Hasil dan Pembahasan}

\subsection{Keputusan Memilih Bertempat Tinggal di Rusunawa oleh Sandwich Generation Sebelum dan Selama Pandemi}

Pemilihan tempat tinggal merupakan suatu hal yang bersifat dan bernilai fundamental bagi sebagian besar masyarakat. Kemudian, tempat tinggal tersebut pada akhirnya menciptakan suatu adanya interaksi sosial di dalamnya. Namun interaksi sosial yang terjadi tidak selamanya terjadi secara asosiatif, melainkan sangat memungkinkan bagi terciptanya interaksi sosial disosiatif. Interaksi sosial disosiatif merupakan bentuk 
interaksi sosial yang mengarah pada konflik. Munculnya konflik sosial dapat dipicu oleh beberapa faktor. Sebagai contoh, menurut (Rahmah et al., 2019) dalam jurnalnya mengatakan bahwa menantu dan mertua yang tinggal dalam satu tempat tinggal yang sama dapat memunculkan suatu konflik. Faktor-faktor penyebabnya adalah mertua sering ikut campur, mertua yang kerap membandingkan menantu, dan menikah tanpa restu orang tua (Rahmah et al., 2019). Melalui pemaparan tersebut dapat dikatakan bahwa tinggal bersama dengan mertua apalagi untuk menantu perempuan dapat menimbulkan perasaan tidak nyaman bagi seseorang. Hal tersebut berakibat pada pemilihan tempat tinggal untuk keluar dari tempat tinggal yang mereka huni sebelumnya. Oleh karena itu, ketersediaan rusunawa di daerah perkotaan dapat dijadikan sebagai solusi dan juga pilihan bagi masyarakat yang tidak ingin tinggal bersama, baik dengan orang tua, mertua, ataupun saudara dalam satu rumah.

Tak terkecuali pula oleh sandwich generation, keberadaannya di dalam ruang perkotaan dalam pemilihan keputusan tempat tinggal menjadi sangat relevan dengan tersedianya rusunawa yang ada. Selain karena faktor keluarga pada kebersamaan tempat tinggal seperti contoh kasus di atas, keputusan memilih rusunawa sebagai tempat tinggal sebelum pandemi oleh sandwich generation didasari atas faktor ekonomi. Beberapa alasan oleh sandwich generation yang telah diwawancarai adalah mereka merupakan perantau yang tak memiliki banyak uang, namun juga ingin bergaya. Kemudian, keinginan untuk hidup hemat dengan menghiraukan gengsi juga termasuk ke dalam salah satu alasan memilih tempat tinggal di rusunawa. Pada dasarnya ketersediaan rusunawa menjadi solusi untuk sandwich generation dalam memiliki tempat tinggal yang layak. Selain itu, adanya rusunawa juga menjadi sebuah solusi bagi mereka yang memiliki upah kerja cukup, namun cenderung kurang atau termasuk ke dalam golongan Masyarakat Berpenghasilan Rendah (MBR), memiliki banyak tanggungan keluarga serta menanggung hidup dirinya sendiri.

Masa Pandemi Covid-19 yang telah menyerang Indonesia selama hampir 2 tahun tersebut berakibat pada kenaikan kebutuhan tempat tinggal masyarakat. Hal tersebut terjadi karena kebijakan pemerintah untuk melakukan Work From Home (WFH). Kebijakan Work From Home (WFH) yang dikeluarkan membuat masyarakat harus melakukan serta menjalankan sebagian besar segala aktivitasnya di rumah (Anonim, 2021a). Namun, perubahan terhadap kenaikan kebutuhan tempat tinggal tersebut tidak dibarengi oleh kenaikan pendapatan masyarakat Indonesia, khususnya sandwich generation di Provinsi Jawa Timur. Kemudian untuk memperkuat pernyataan tersebut dapat dibandingkan melalui data yang diperoleh melalui BPS tahun 2019, 2020, dan 2021 dengan hasil sebagai berikut:

Tabel 2. Rata-Rata Upah Sektor Formal

\begin{tabular}{lll}
\hline Tahun & Generasi X & Generasi $Y$ \\
\hline 2018 & $2.221 .585,60$ & $2.167 .596,50$ \\
\hline 2019 & $3.476 .329,35$ & $2.721 .012,06$ \\
\hline 2020 & $2.804 .393,25$ & $2.413 .136,33$ \\
\hline
\end{tabular}


Data BPS tahun 2019-2021 tersebut menjelaskan mengenai rata-rata upah sektor upah formal pada generasi $Y$ dan generasi $X$ dalam angka satuan juta. Dapat diketahui bahwa pada tahun 2018 ke 2019 rata-rata upah generasi $Y$ dan generasi $X$ telah mengalami kenaikan. Pada tahun 2018 ke 2019 rata-rata upah generasi Y mengalami kenaikan sebesar Rp 553.415,56. Kemudian angka kenaikan rata-rata upah generasi X di tahun 2018 ke 2019 sebesar Rp 1.254.743,75. Sedangkan, di tahun 2020 rata-rata upah baik generasi $Y$ maupun $X$ mengalami penurunan. Rata-rata upah generasi $Y$ mengalami penurunan sebesar Rp 303.875,73. Sedangkan pada generasi $X$ mengalami penurunan rata-rata upah yang cukup signifikan dibandingkan generasi $X$, yaitu sebesar Rp 671.936,1.

Salah satu sasaran Rencana Strategis (Renstra) Kementerian Pekerjaan Umum dan Perumahan Rakyat Tahun 2020-2024 adalah meningkatnya penyediaan akses perumahan dan infrastruktur permukiman yang layak, aman, dan terjangkau. Sejalan dengan Sasaran Rencana Strategis (Renstra) tersebut Kementerian Pekerjaan Umum dan Perumahan Rakyat Tahun 2020-2024 memiliki sasaran terhadap peningkatan kontribusi pemenuhan kebutuhan rumah layak huni dengan melakukan pembangunan rumah susun MBR 18.380 unit (PUPR, 2020).

Tabel 3. Data Pertambahan Jumlah Rusunawa Provinsi Jawa Timur

\begin{tabular}{ll}
\hline Tahun & Jumlah (Unit) \\
\hline 2018 & 2.260 \\
\hline 2019 & 980 \\
\hline 2020 & 649
\end{tabular}

Sumber: Kementerian Pekerjaan Umum dan Perumahan Rakyat

Menurut data yang diperoleh dari Kementerian Pekerjaan Umum dan Perumahan Rakyat pada tahun 2018 hingga 2020 terdapat total sebanyak 3.889 unit rusunawa yang tersebar di Provinsi Jawa Timur. Jumlah tersebut kian bertambah 980 unit dari tahun 2019 yang kemudian bertambah kembali sebanyak 649 unit di tahun 2020. Data banyaknya jumlah rusunawa tersebut pada akhirnya sejalan dengan sasaran Rencana Strategis (Renstra) Kementerian Pekerjaan Umum dan Perumahan Rakyat Tahun 20202024 bahwa akan melakukan pembangunan sebanyak 51.340 unit rumah susun. Kemudian dapat diketahui bahwa keputusan memilih tempat tinggal oleh sandwich generation di rusunawa sangat dipengaruhi oleh faktor ekonomi dan ketersediaan rusunawa di Provinsi Jawa Timur. Rata-rata upah sandwich generation yaitu generasi $Y$ dan generasi $X$ yang mengalami penurunan di tahun 2020 selama pandemi covid-19 membuktikan bahwa akses untuk memiliki tempat tinggal yang layak semakin sulit untuk didapatkan. Adanya rusunawa di Provinsi Jawa Timur pada akhirnya dapat memberikan sedikit angin segar bagi sandwich generation yang sedang terhimpit ekonomi, namun membutuhkan tempat tinggal yang layak. 
Menurut Turner dalam teorinya yang bernama Housing as a Process dapat dianalisis melalui tiga hal, yaitu: nilai rumah, fungsi ekonomi rumah, dan wewenang atas rumah (Ingold, 2000). Teori Housing as a Process melalui buku yang berjudul Freedom to Build, menyatakan bahwa rumah bukan merupakan hasil dari fisik sekali jadi, melainkan suatu proses yang terus berkembang dan terkait dengan mobilitas sosial ekonomi penghuninya dalam kurun waktu (Ingold, 2000). Fungsi yang ada tersebut sangat tergantung pada orientasi tujuan yang ingin dicapai oleh seseorang. Tujuan yang ingin dicapai juga tergantung pada tempat dan waktu dalam interaksi antara lingkungan tempat tinggal dengan penghuninya. Dalam penelitian ini interaksi yang terjalin adalah antara keputusan pemilihan tempat tinggal bagi sandwich generation dengan lingkungan terletak pada tujuan untuk menghemat pengeluaran karena adanya himpitan ekonomi.

Dalam teori Housing as a Process terdapat dua faktor yang dipakai untuk mengukur nilai rumah. yaitu faktor moneter dan faktor non-moneter. Faktor moneter meliputi pendapatan rumah tangga, biaya operasional kelangsungan rumah, cost (tanah, bangunan, dan fasilitas lain), serta modal yang dimiliki oleh penghuni dari kepemilikan rumah. Sedangkan faktor non-moneter meliputi pencapaian, baik pada penghasilan maupun pencapaian sosial, keamanan berdiam atau tinggal, serta standar fisik bangunan dan lingkungan (Turner, 1997). Meskipun pemilihan tempat tinggal oleh sandwich generation di rusunawa ini telah memperhatikan faktor moneter, nyatanya beberapa dari mereka lebih memilih tinggal di rusunawa dengan alasan himpitan ekonomi, adanya beban keluarga, dan tanpa memperhatikan faktor non-moneter di dalamnya. Di sisi lain ada juga sandwich generation yang telah memperhatikan faktor non-moneter di dalamnya yaitu dengan memilih rusunawa karena dinilai sebagai hunian yang lumayan layak.

Turner dalam teorinya pada Housing as a Process juga berbicara mengenai fungsi ekonomi rumah dan wewenang atas rumah. Fungsi ekonomi rumah merupakan usaha guna menghasilkan perumahan yang ekonomis dan menitikberatkan pada pemanfaatan sumberdaya yang mereka miliki. Sedangkan wewenang atas rumah yang dimaksud adalah pengguna dapat mengendalikan proses pengambilan keputusan utama dan bebas memberikan masukan dalam perancangan pembangunan atau pengelolaannya, proses dan lingkungan yang dihasilkan akan merangsang kesejahteraan dari perorangan ataupun masyarakat (Turner, 1997).

Pernyataan tersebut tak sesuai dengan kondisi pada pengambilan keputusan untuk bertempat tinggal di rusunawa oleh sandwich generation. Mereka sama sekali tidak memiliki fungsi ekonomi maupun wewenang atas rumah. Para sandwich generationyang tinggal di rusunawa tidak menampakkan bahwa mereka sedang memanfaatkan sumberdaya yang mereka miliki. Seperti pernyataan sandwich generation yang berdomisili di Probolinggo menyatakan bahwa menempati rusunawa karena keterbatasan ekonomi dan tidak ingin tinggal bersama mertua. Kemudian, jika ingin membuka toko kelontong dengan memanfaatkan situasi rusunawa yang ramai dengan 
anak kecil juga tidak memiliki modal yang cukup (LA, 37 tahun, Oktober 2021). Selain itu, wewenang atas rumah menjadi hal yang tak dapat dijangkau karena rusunawa merupakan sebuah pemukiman subsidi dengan status sewa.

Pada akhirnya faktor keputusan utama untuk pemilihan tempat tinggal oleh sandwich generation di rusunawa tertuju pada himpitan ekonomi. Faktor ekonomi menjadi faktor penentu bagi sandwich generation, baik sebelum maupun selama pandemi Covid-19. Rusunawa adalah tempat tinggal yang menjadi sebuah solusi dan jawaban atas segala permasalahan sandwich generation yang memiliki upah biasa saja, namun menanggung beban keluarga yang banyak dan juga dirinya sendiri. Selain itu, alasan lainnya adalah rusunawa merupakan tempat tinggal yang lumayan layak tanpa mengeluarkan biaya yang mahal, seperti membeli rumah, sewa kos atau pun rumah.

\subsection{Siapa yang Mengintai Warga Rusunawa Selama Pandemi: Covid-19 atau Kelaparan?}

Permasalahan sandwich generation pada masa sebelum pandemi erat dikaitkan dengan beban pengasuhan atas tuntutan yang berasal dari orang tua dan anak. Beban pengasuhan yang dimaksud pada sandwich generation adalah mengasuh orangtua yang dirawatnya dan anak yang harus diasuhnya pula. Menurut (Salmon, 2017) dampak negatif dari peran dan tanggung jawab sandwich generation tidak hanya pada beban pengasuhan saja, namun juga pada segi fisik, psikologis, emosional, dan juga beban keuangan (Kusumaningrum, 2018). Sandwich generation diibaratkan sebagai pengasuh dan menurut Novak \& Guest (1989) sangat berpotensi pada beban fisik, sosial, dan emosional, beban ekonomi untuk perawatan kesehatan menurut Emanuel, Fairclough, Slutsman, \& Emanuel (2000), aktivitas seksual dengan pasangan yang menurun menurut Simonelli, dkk (2008) (Kusumaningrum, 2018). Serta menurut Chang, Chiou, \& Chen (2010) kesehatan mental pada pengasuh juga penting pada kesehatan fisiknya (Kusumaningrum, 2018). Dampak negatif pada beban pengasuhan sandwich generation akhirnya memunculkan perilaku bahwa mereka ingin keluar dari rumah dan mencari tempat tinggal lainnya. Tak beda halnya dengan pernyataan informan yang telah diwawancara. Mereka mengatakan bahwa motivasi ingin keluar dari rumah dan memutuskan untuk tinggal di rusunawa dikarenakan keinginan bebas secara mandiri serta tidak ingin diintervensi oleh keluarga.

Tujuan direktorat pembangunan rumah susun adalah sebagai upaya pemenuhan kebutuhan perumahan dan infrastruktur permukiman yang layak dan aman menuju terwujudnya smart living, dengan pemanfaatan dan pengelolaan yang partisipatif untuk meningkatkan kualitas hidup masyarakat (PUPR, 2020). Pernyataan salah satu sandwich generation yang tinggal sebagai warga rusunawa di Provinsi Jawa Timur berbanding terbalik dengan tujuan dari pembangunan rumah susun oleh Kementerian Pekerjaan Umum dan Perumahan Rakyat. Situasi dan kondisi yang mereka alami menjadi tidak aman karena mereka terancam akan banyaknya orang yang bertempat tinggal di rusunawa. Apalagi, selama masa pandemi warga rusunawa menjadi lebih khawatir akan penyebaran virus Covid-19 di sekitar lingkungan rusunawa. Lalu, bagaimana definisi dari pemukiman yang layak dan aman yang sesungguhnya? 
Bangunan rusunawa Kota Madiun tahap dua nyatanya telah dijadikan tempat isolasi bagi pasien terkonfirmasi Covid-19, namun ruang isolasi tersebut hanya dikhususkan untuk ASN dan tenaga medis (PPID, 2021). Juga pada rusunawa Universitas Brawijaya (UB) juga telah menjadikan rusunawa sebagai tempat isolasi bagi pasien Covid19 yang berstatus Orang Tanpa Gejala (OTG) (Anonim, 2021). Hal tersebut menjadi kontradiktif atas tujuan dibangunnya rusunawa sebagai pemenuhan perubahan dan infrastruktur yang layak serta aman hingga terwujudnya smart living di Indonesia. Sebetulnya, ketersediaan rusunawa di era pandemi Covid-19 sangat membantu dan menjadi sebuah jawaban atas permasalahan masyarakat yang menginginkan tempat tinggal dengan harga sewa murah. Namun, berubahnya fungsi rusunawa menjadi tempat isolasi bagi pasien terkonfirmasi Covid-19 membuat masyarakat menjadi lebih khawatir akan kebutuhan tempat tinggal, khususnya bagi sandwich generation di tengah ruang perkotaan.

Kekhawatiran sandwich generation di era pandemi bukan berfokus pada ketakutan akan pandemi Covid-19 itu. Melainkan ketakutan-ketakutan bahwa mereka tidak akan bisa makan dengan layak dan merasakan kelaparan. Narasi lainnya adalah penolakan rusunawa yang dijadikan sebagai shelter atau penampungan pasien terkonfirmasi Covid-19 dengan status Orang Tanpa Gejala (OTG). Bahkan, mereka tidak memiliki keberanian untuk mengikuti demo akan hal itu karena tempat tinggal yang dihuninya berstatus rumah sewa. Artinya, pandemi Covid-19 menjadi sebuah ancaman bagi sandwich generation untuk melangsungkan kehidupannya dalam hal mencari makan maupun tempat tinggal di tengah ruang perkotaan. Ditambah lagi, jumlah pengangguran di Provinsi Jawa Timur mengalami kenaikan yang cukup tinggi. Pada tahun 2019 angka pengangguran di Provinsi Jawa Timur sebesar 21.499.000 jiwa kemudian mengalami kenaikan di tahun 2020 sebesar 22.264.000 jiwa. Artinya kenaikan jumlah angka pengangguran yang terlihat seperti gambar di bawah sebesar 1,92\% sebanyak 457.391 jiwa.

Tabel 4. Jumlah Pengangguran di Provinsi Jawa Timur

\begin{tabular}{ll}
\hline Tahun & Persentase (\%) \\
\hline 2019 & 3,92 \\
\hline 2020 & 5,84
\end{tabular}

Sumber: Olahan Data BPS Provinsi Jawa Timur Tahun 2019-2021

Melalui data jumlah pengangguran di Provinsi Jawa Timur tersebut dapat dikatakan bahwa keterbatasan ekonomi menjadi penghalang bagi sandwich generation untuk memiliki kesempatan mencari makan dan tempat tinggal berkenaan dengan apa yang mereka inginkan. Sandwich generation terkesan tidak memiliki pilihan terkait tempat tinggal yang mereka pilih untuk aman dari pandemi Covid-19 karena mereka lebih takut kelaparan.

Masyarakat yang paling rentan dalam sosial-ekonomi sering ditempatkan pada wilayah yang rentan secara fisik dan lingkungan (Vale, 2014). Lahan yang langka dan biaya 
perumahan yang seringkali memaksa penduduk miskin untuk tinggal di kawasan perkotaan yang rawan banjir. Sesuai dengan pernyataan tersebut, keberadaan rusunawa di Provinsi Jawa Timur telah sengaja dihadirkan bagi mereka yang rentan akan kehidupan sosial-ekonomi, khususnya sandwich generation. Namun, ketahanan perkotaan juga diciptakan dalam bentuk yang berbeda atau bervariasi untuk mencapai keadaan yang stabil. ketahanan kota juga dibuat oleh para pejabat pemerintah, swasta dan politik (Vale, 2014). Pernyataan tersebut, akhirnya sejalan dengan kebijakan pengalihfungsian rusunawa di Provinsi Jawa Timur sebagai shelter untuk tempat isolasi pasien terkonfirmasi Covid-19, apalagi tingkat pengangguran yang ada di Provinsi Jawa Timur juga telah mengalami kenaikan sebesar 1,92\%. Keikutcampuran pejabat pemerintah, pihak swasta, dan keterkaitan politik telah menjadi momok bagi sandwich generation sebagai masyarakat yang rentan di tengah ruang perkotaan dalam pemilihan tempat tinggal.

\subsection{Kerancauan Resiliensi Perkotaan Rusunawa dalam Pandangan Sandwich Generation}

Menurut Holling (1973), makna dari resiliensi adalah penekanan pada konteks daya tarik dan kegigihan atas seberapa mau manusia melakukan proses berjuang secara gigih. Dalam konteks resiliensi dunia dianggap secara acak dan tidak dapat diprediksi. Selain itu, ketahanan juga dapat diartikan tentang cara beradaptasi dan mengurangi kerentanan (Chelleri, 2012). Kerangka ketahanan tersebut memiliki konsep dari tiga kata kunci utama, yaitu mempertahankan, memulihkan dan mencari keseimbangan (Chelleri, 2012). Holling juga mendefinisikan bahwa ketahanan dalam ekosistem berperan sebagai kapasitas sistem guna mengatur ulang dan mengelola perubahan untuk mempertahankan identitas, struktur dan fungsi yang sama (Holling, 1973).

Bagi sandwich generation yang tinggal di rusunawa, kemunculan pandemi Covid19 dianggap seperti sebuah ancaman besar. Mereka diharuskan hidup berdampingan dengan Covid-19 apalagi memiliki keterbatasan ekonomi. Kondisi tersebut semakin menjepit sandwich generation dengan segala keterbatasan akses untuk melakukan resiliensi. Tak mudah bagi sandwich generation untuk melakukan perubahan di tengah ancaman dan bahaya yang sedang mengintai mereka. Segala aktivitas dan sikap yang sandwich generation ambil terkesan tidak berdampak apapun pada kehidupan mereka. Kehidupan sandwich generation di tengah ruang perkotaan pada akhirnya tidak membuat mereka resiliensi meskipun mereka telah memilih tempat tinggal di rusunawa.

Sesuai dengan kunci utama dari kata ketahanan perkotaan atau resiliensi menunjukkan bahwa sandwich generation masih dalam posisi hanya sebatas 'mempertahankan' dan belum berada pada tahap memulihkan serta mencari keseimbangan. Sesuai dengan pernyataan Matyas bahwa terdapat tiga gaya resiliensi, yaitu resistance, incremental adjustment, transformation (Matyas et al., 2014). Sandwich generation di tengah ruang perkotaan masuk ke dalam gaya resiliensi incremental adjustment yang mana mereka hanya melakukan penyesuaian atas berbagai himpitan yang menekannya. Sandwich generation yang berada di tengah ruang perkotaan dan 
bertempat tinggal di rusunawa mengalami kondisi yang stagnan akibat ancaman yang muncul, yaitu pandemi Covid-19 itu sendiri. Pernyataan dari sandwich generation bahwa mereka tidak dapat melakukan apapun dan hanya diam karena tidak memiliki sumberdaya atau alasan yang cukup kuat guna melakukan resiliensi akibat status 'rumah sewa' pada rusunawa itu sendiri. Ironisnya para sandwich generation masih berpikir bahwa mereka harusnya berterima kasih pada pemerintah atas penyediaan rusunawa di Provinsi Jawa Timur. Di sisi lain sandwich generationjuga merasa terancam dan khawatir tergusur ketika bertempat tinggal di rusunawa karena pengalihfungsian rusunawa menjadi shelter pasien terkonfirmasi Covid-19 dan juga terdapat kekhawatiran yang tinggi akan tertularnya virus Covid-19 kepada mereka dan juga keluarganya.

\section{Kesimpulan dan Saran}

Pemilihan tempat tinggal di rusunawa oleh sandwich generation di kawasan perkotaan Provinsi Jawa Timur menunjukkan bahwa faktor ekonomi menjadi faktor dominan. Secara teoritik dalam kajian resiliensi perkotaan, pemilihan rusunawa pada sandwich generation di Provinsi Jawa Timur jauh dari kata resilien dalam ranah perkotaan. Resiliensi lebih menekankan pada konteks daya tarik dan kegigihan perjuangan manusia sebab dunia tidak dapat diprediksi dan dianggap acak. Maka untuk mengetahui ketahanan generasi sandwich generation di masa pandemi harus ditilik dari sisi kapasitas ekonomi, ekosistem, manusia, masyarakat dan sistem perkotaan untuk mengatasi gangguan. Namun yang muncul dalam generasi tersebut dalam keputusan memilih tempat tinggal lebih mengedepankan dari sisi ekonomi daripada kapasitas lainnya. Hingga memasuki masa pandemi, kebijakan pemerintah untuk menempatkan para orang tanpa gejala (OTG) Covid-19 di rusunawa pada dasarnya mengalami beberapa penolakan oleh para penghuni rusunawa, namun pada kenyataannya para informan tidak dapat melakukan perlawanan karena merasa sadar diri dengan status kepemilikan rusunawa yang hanya sebagai penyewa. Berdasarkan hasil penelitian ini, sebenarnya diperlukan proses dialogis antara pemerintah (sebagai pemegang kebijakan atas situasi

pandemi dan pemilik rusunawa) untuk dapat menjalin komunikasi dengan lebih baik lagi bersama dengan para sandwich generation agar tujuan dari rusunawa yang termaktub dalam Renstra terkait peningkatan kualitas hidup dari masyarakat yang tinggal di rusunawa dapat tercapai sehingga konflik terbuka atau pun terselubung dapat terhindarkan. Dengan demikian, cita-cita menciptakan kota yang resilien dapat terwujud pada implementasi pembangunan rusunawa di semua kawasan di Indonesia, terlebih juga pada Provinsi Jawa Timur.

\section{Daftar Pustaka}

Anonim. (2021). Ada Pandemi, Kebutuhan Rumah Semakin Tinggi. Kompas.Com. https://www.kompas.com/homey/read/2021/06/08/142013776/ada-pandemikebutuhan-rumah-semakin-tinggi. 
Anonim. (2021). Tambah Tempat Isolasi OTG, Rusunawa UB Segera Dimanfaatkan. JPNN.Com. https://jatim.jpnn.com/dadi-omongan/2264/tambah-tempatisolasi-otg-rusunawa-ub-segera-dimanfaatkan.

Anonim. (2021). Kenali Generasi Sandwich, Apakah Kamu Salah Satunya? Jaringan Prima. https://www.jaringanprima.co.id/id/kenali-generasi-sandwich-apakahkamu-salah-satunya.

BPS. (2019). Provinsi Jawa Timur dalam Angka 2019. BPS Provinsi Jawa Timur.

BPS. (2020). Provinsi Jawa Timur Dalam Angka 2020. BPS Provinsi Jawa Timur.

BPS. (2021). Provinsi Jawa Timur Dalam Angka 2021. BPS Provinsi Jawa Timur.

Bratakusumah, D. S. (2000). Penyelenggaraan Kewenangan dalam Konteks Otonomi Daerah. Naskah, 20,1-7.

Campanella, T. J. (2006). Urban resilience and the recovery of new orleans. Journal of the American Planning Association, 72(2), 141-146. https://doi.org/10.1080/01944360608976734

Chang, H. Y., Chiou, C. J., \& Chen, N. S. (2010). Impact of mental health and caregiver burden on family caregivers' physical health. Archives of Gerontology and Geriatrics, 50(3), 267-271.

Chelleri, L. (2012). From the "Resilient city» to urban resilience. a review essay on understanding and integrating the resilience perspective for urban systems. Documents d'Analisi Geografica, 58(2), 287-306. https://doi.org/10.5565/rev/dag.175.

Creswell, J. W. (2014). Research Design Fourth Edition. Sage: Los Angeles.

Day, L.L. (2000). Choosing a house: The relationship between dwelling type, perception of privacy and residential satisfaction. Journal of Planning Education and Research, 19, 265-275.

Emanuel, E. J., Fairclough, D. L., Slutsman, J., \& Emanuel, L. L. (2000). Understanding economic and other burdens of terminal illness: The experience of patients and their caregivers. Annals of Internal Medicine, 132(6), 451-459.

Fang, Y. (2006). Residential satisfaction, moving intention and moving behaviors : a study of redeveloped neighborhood in inner-city Beijing. Housing Studies, 21, 671-694. 
Herindiyati. (2016). Penyusunan Program Rumah Susun Sewa di Kawasan Perkotaan. E-Journal Universitas Borobudur, 66-82.

Holling, CS (1973). «Resilience and stability of ecological systems».Annual Review of Ecology and Systematics, 4, 1-23.

Husain, S. A., Wilodati, \& Sartika, R. (2021). Sandwich Parenting: Pola Asuh Keluarga Abad 21. Sosietas 11, 8(11), 1002-1014.

Ingold, T. (2000). The Perception of the Environment Essays on livelihood, dwelling and skill. In Routledge.

Kusumaningrum, F. A. (2018). Generasi Sandwich: Beban Pengasuhan dan Dukungan Sosial pada Wanita Bekerja. PSIKOLOGIKA Jurnal Pemikiran Dan Penelitian Psikologi Jurnal Pemikiran Dan Penelitian Psikologi, 23(2), 109-120. https://doi.org/10.20885/psikologika.vol23.iss2.art3.

Matyas, D., Regional, S., Adviser, R., Pelling, M., \& Kingdom, U. (2014). Positioning resilience for 2015: the role of resistance, incremental adjustment and transformation in disaster risk management policy. Disasters, 39, 1-19. https://onlinelibrary.wiley.com/doi/abs/10.1111/disa.12107.

Novak, M., \& Guest, C. (1989). Application of a multidimensional caregiver burden inventory. The Gerontologist, 29(6), 798-803.

Padawangi, R. (2018). Kota Sosial: Aspirasi Transformasi Perkotaan di Asia. In Friedrivh Ebert Stiftung. Friedrich Ebert Stiftung.

PPID. (2021). Rusunawa Tahap // Kota Madiun Difungsikan sebagai Tempat Isolasi. DPKP Madiun. https://dpkp.madiunkota.go.id/rusunawa-tahap-ii-kotamadiun-difungsikan-sebagai-tempat-isolasi/.

PUPR, K. (2020). Rencana Strategis Direktorat Rumah Susun 2020 -2024.

Rahmah, M., Quraisy, H., \& Risfaisal. (2019). Konflik Sosial Menantu yang Tinggal Serumah dengan Mertua (Studi Kasus di Desa Lempang Kecamatan Tanete Riaja Kabupaten Barru). Jurnal Pendidikan Sosiologi, VI/(2), 206-210.

Rahmawati, I. (2018). Identitas Sosial Warga Huni Rusunawa. MEDIAPSI, 4(2), 76-82. https://doi.org/10.21776/ub.mps.2018.004.02.3. 
Rahmawati, I., \& Sari, N. (2020). Persepsi Rusunawa Ideal Pada Warga Huni Rusunawa Buring, Malang. Sustainable, Planning and Culture $\quad$ (SPACE): Jurnal Perencanaan Wilayah Dan Kota, 2(1), 1-4. https://doi.org/10.32795/space.v2i1.825.

Salmon, S. A. (2017). The Sandwich Generation: Effects of Caregiver Burden and Strategies for Assessment. Utah: Westminster College.

Turner, J. F. . (1997). Housing By People. PANTHEON BOOKS.

Vale, L. J. (2014). The politics of resilient cities: Whose resilience and whose city? Building Research and Information, 42(2), 191-201. https://doi.org/10.1080/09613218.2014.850602. 